\title{
OBITUARY.
}

\section{THE LATE MR. HORACE L. SHORT.}

The Services, the science of aircraft design, and the industry of seaplane froduction have sustained an irreparable loss in the sudden death, on April r6th last at his residence in the Isle of Sheppey, of Mr. Horace L. Short, the eldest of the three brothers whose products are known the world over.

Though only 44 years of age the late Mr. Horace L. Short crowded as much: into his life's work as would have sufficed for the careers of half a dozen ordinary men. Whatever he undertook became forthwith a medium for practical pioneering on his part. Long before he gave his attention to the proposition of aerial navigation he had furnished many proofs of a remarkable originality combined with that even more rare quality, the ability to think and act in practical terms.

To say that we owe the British seaplane industry to his foresight and genius is almost to understate the case, in that to-day the influence of his work spreads. far beyond these islands, and even the Empire. Born in 1874, he was educated. at Risley Latin School, whence he proceeded to a course of engineering training in the shops of the Stanton Iron Works, Notts. Subsequently he was at Evlin Compton's Works at Chelmsford, and later at Chatham Dockyard.

His love of the romance of life, as well as the spirit of adventure that is inherent in all pioneering natures, soon induced him to travel. In the issue few men have voyaged more widely or done a more various share of the world's work. Only at rare intervals could one induce him to recount any of his experiences. They were never for the ear of strangers; nor were they ever told for telling's sake, but only to illustrate some phase either of human nature or of human enterprise. He never seemed to thin that there was anythingremarkable in himself, all his wonder being absorbed in the marvellousness of this world. He was a man not content merely with looking at things. What he saw he pondered deeply, with the result that, if he had elected to commit his views on almost any subject of human interest to paper, the world would have been the richer for fresh and eminently helpful ider .

His first long voyage was to Australia in a sailing ship, a mode of travel of which he had much subsequent experience and which always fascinated him, cespite the fact that on many occasions the risks he ran in strange seas were such that few men would care to share. In Australia he undertook various contracts. for sheep shearing machinery. Next he went to the South Sea Islands. There he was captured by cannibals, a chapter of his life's history which, if told in detail, would thrill schoolboys throughout the Empire and make many superior persons well-nigh incredulous. On his escape he returned to Australia. Afterwards he visited China, whence he proceeded to San Francisco, where he was. engaged for a while in putting machinery into ships.

His next venture was in connection with a large silver mine in Mexico, called the Panuco. Here he worked as Chief Engineer for four or five years and, despite all difficulties in his path, succeeded in introducing air-compressed machinery driven by water turbines; thereby revolutionising the whole manner of working the rnine in question.

It was at this period that he made experiments with the articulating syren, otherwise known as the Auxetophone. He made such progress that he returned 
to Europe for the express purpose of developing the invention, bringing it to a fair pitch of perfection after devoting some months to it. The tale of grand opera being rendered to the ever-receptive Parisian public from the top of the Eiffel Tower by this means illustrates one only of many developments that Horace Short loved to introduce, quite anonymously, alike to civilised and to savage life. In the meantime his restless nature caused him to visit the Ashanti Gold Fields. for three months. Contracting fever, however, he was fain to return to the old country, where he continued experimenting with the Auxetophone and also assisting in certain experiments with printing machinery.

As a result of this work he joined Sir Charles Parsons at Newcastle, assisting: him in his experiments with steam turbines, among other even more romantic matters. It was while engiaged on this work that his two younger brothers, Eustace and Oswald, invited him to join them in experimenting with dirigible balloons, an offer which was accepted in 1907. Those were the years when aviation was beginning to be recognised as practicable. He became fascinated with the idea of the heavier-than-air machine, to which branch he decided to. devote his entire energies. A few months later he met Wilbur Wright at Le Mons. After watching his flights and studying his experiments Horace Short obtained a contract to build the Wright biplane in England. This work was. carried out at Shell Beach, Isle of Sheppey, where those of us who were already enthusiasts in those seemingly so distant days used to spend some of the happiest and most memorable hours of our lives watching the early pilots " hatch eggs," studying the weak points of such engines as were then available, and being fascinated by the fertile brain of Horace Short as he dealt with one knotty problem: after another that arose in connection with the evolution of aircraft. Even then his love of the open sea made him appreciate to the full the possibilities of the seaplane. His first notable success, however, was with a land machine, the biplane he designed and built for Mr. (now Major) J. T. C. Moore-Brabazon winning the "Daily Mail's" $£ \mathrm{r}, 000$ prize for the first circular flight of a mile by an all-British aeroplane. That was in November, 1909.

Thereafter, development was rapid. Together with his brothers, Horace Short moved the establishment to Eastchurch and there built the biplanes on which the first four officers appointed by the Admiralty to the Royal Flying Corps (Naval Wing) for flying duties were taught to become pilots.

In 1912 his seaplanes were realising dreams that Jules Verne himself might have dreamt. In that year Commander C. R. Samson, R.N., made the first flight from a battleship, H.M.S. " Africa."

Horace Short's famous folding wing seaplane, which made it possible to. carry seaworthy aircraft on ships of moderate size, also to house the largest types of aircraft in sheds of reasonable dimensions, was produced in the following year. From that period onwards one development followed another with increasing rapidity, for he realised the value of the new weapon to the greatest naval power in the world in the event of war, and that event materialised with appalling suddenness, hence he did not spare himself. On Christmas Day, 1914, a raid was. carried out on Cuxhaven by several Short seaplanes, while on another occasion Squadron Commander Seddon, R.N., flew from the Isle of Grain to Plymouth. in quest of a lost submarine. Again a Short seaplane was the machine used by Flight Lieut. Rutland in the historic task that officer achieved during the greatest naval engagement in history, the Battle of Jutland. For obvious reasons one cannot give anything like a complete list of the notable parts played by Short aircraft in this war. Hence, one illustrates their further use merely by adding one example, namely, the dropping of flour on Kut during the time Greneral Townsend was besieged with the gallant garrison there. Had something like six times the number of machines been available that fine leader need never have: surrendered for lack of food supplies. 
In any other country than this such a man as Horace Short would have found his name a household word, and his story would have been one of the most familiar among all classes of the community. But he ever shrunk from aught in the guise of publicity, so that even in aviation circles only a small percentage of enthusiasts knew anything about the man's personality. All who knew him not merely admired him enormously, they, besides, acquired a degree of affection for him beyond the ordinary. What the British Navy owes to him it is impossible adequately to state. The lapse of years will cause his work to emerge in true perspective. Then we may look for his name to figure as the foremost of our pioneer aircraft constructors. No better testimony of this can be offered than the unanimous decision of the British aircraft industry to raise a suitable memorial to him at the earliest opportunity. His colleagues realise, of course, that such a man would not consider the present to be such an opportunity, for if ever there was a man who understood this war in all its awful seriousness and who had an intelligent grasp of its mighty consequences to the destinies of the world, his name was Horace Short. When we shall have finished the war, and not before, would such a nature welcome the notion of a memory being perpetuated and a man's work being commemorated.

Horace Short was both a man of fertile, fresh and great ideas, and a master builder. Of him it could not be written that he " builded better than he knew," because he knew how to build the best possible and strove with his very might to make all associated with him attain to his ideal. "Short built" are words which, when they come from the mouth of a man in the Services, mean that which proves Horace Short succeeded in inspiring his fellow workers to achieve the highest standard attainable. In the workshop no man could be more justly severe in censure. His overseeing was always to ensure "safety first." And his work has placed the British seaplane industry in that relation to that of other nations which has long been occupied by our shipbuilding industry in its own kind. When he said "No" about a proposed construction not even the Admiralty would press the matter further. The man has not been born who could shift him from a fact, nor does the world hold the money that could have tempted him to depart from a conviction.

Happily, both the science has progressed to such, a stage and our native aircraft industry has become sufficiently developed for us to be able to carry on, though robbed untimely of a brain so resourceful, so rarely practical and so original. Comparatively young in years, but old both in experience and in achievement of the first quality, Horace Short's name will ever be held in the highest regard by all Britons who cherish their country and value the type of leaders who, from generation to generation, have made this Empire what it is. The nation is the richer for his life and work.

H. M. B. 